\title{
How populists securitize elections to win them: the 2015 double elections in Turkey
}

\author{
Osman Şahin
}

\begin{abstract}
This study presents a new theoretical framework for understanding one of the ways in which populists generate support in elections. It argues that populist movements securitize elections by triggering perceptions of ontological insecurity among voters. Through this strategy, populist movements amplify voters' negative image of the country they live in and the challenges they face, which contributes to populist movements' electoral success. Building upon this theoretical framework, this study offers an explanation for the 2015 double general elections in Turkey. The Justice and Development Party (Adalet ve Kalkınma Partisi, AKP) experienced disappointment after losing its parliamentary majority in the June 2015 elections. However, the AKP increased its votes by 8.6 percent in the November 2015 elections. Between these two elections, the AKP had used the Kurdish question to trigger perceptions of ontological insecurity, which enabled it to securitize the elections in November. This strategy helped the AKP win the November elections.
\end{abstract}

Keywords: Populism; Turkey; Ontological insecurity; Securitization

\section{Introduction}

The populist phenomenon has been in ascendance throughout the world, which causes democratic backsliding ${ }^{1}$ even in consolidated democracies. When in office, populist movements erode the democratic regime with their Manichean view of society, distaste for checks and balances, and intolerance of dissent. ${ }^{2}$ The literature, therefore, requires more research on strategies by which populist movements come

Osman Şahin, Glasgow School for Business and Society, Glasgow Caledonian University, UK, e-mail: osman81sahin@gmail.com

Author's Note: The author would like to thank Sema Akboğa, Harun Ercan, and Erdem Yoruk for their critical comments. The author would also like to thank Umut Korkut and Marcus Nicolson for the insights they provided in the early stages of this article.

1 Jan-Werner Muller, What is Populism? (London: Penguin Books, 2017).

2 Ibid.

New Perspectives on Turkey, no. 64 (2021): 7-30 $\quad$ (c) The Author(s), 2021. Published by Cambridge University Press. This is an Open Access article, distributed under the terms of the Creative Commons Attribution licence (http://creativecommons.org/licenses/by/ 4.०/), which permits unrestricted re-use, distribution, and reproduction in any medium, provided the original work is properly cited. 10.1017/npt.2020.34 
to and to stay in power. This study focuses on securitization of elections as a particular populist strategy. It demonstrates how populists securitize elections by triggering perceptions of ontological insecurity among the people to generate support in the elections.

Securitizing elections by triggering ontological insecurities helps populist movements to promote the perception that the elections are extraordinary moments in which the people should choose leaders who can deliver decisive action against "existential threats threatening the nation." Populist movements argue that only they can deliver this action, as other political actors are weak, indecisive, and/or traitors. This strategy helps populist movements generate support among the electorate, as ontologically insecure people seek to get rid of their insecure state of existence by electing a "strong leader" capable of eliminating existential threats.

Following this theoretical framework, this study focuses on the 2015 double general elections in Turkey. The double general elections in 2015 represent a puzzle in recent Turkish history. In the June 2015 elections, the Justice and Development Party (Adalet ve Kalkınma Partisi, AKP) was down to 40.9 percent from 49.9 percent in the previous elections. This result cost the AKP its parliamentary majority. However, instead of buckling under the calls for negotiations for a coalition government, the AKP forced snap elections in November 2015. In these elections, the AKP proved public opinion polls wrong by garnering 49.5 percent of the votes. This study argues that one of the factors explaining the AKP's comeback in the November 2015 elections was the AKP leadership's ability to draw upon the people's perceptions of ontological insecurity by shifting discourses between the two elections. While the previous AKP discourse prioritized a peaceful solution to the Kurdish question, the new discourse emphasized existential security threats, which triggered the ontological insecurities of the Turkish people. The new AKP discourse used ethnic nationalism to create a rally-around-the-flag effect. ${ }^{3}$ This strategy enabled the AKP to securitize the November 2015 elections, increase its votes primarily among Turkish voters, ${ }^{4}$ and eventually win the elections.

The following section describes the theoretical framework behind the claims of this study. The methodology section explains why discourse analysis

3 Past research demonstrated how political leaders use nationalism in the referendums (and elections) to protect their hegemony. Political leaders employ ethnic nationalism in elections to thwart their opponents' attempts to unseat them. For an example, see Dylan O'Driscoll and Bahar Baser, "Independence Referendums and Nationalist Rhetoric: The Kurdistan Region of Iraq," Third World Quarterly 40, no. 11 (2019): 2016-2034.

4 In the November 2015 elections, the AKP increased its votes not only in the Turkish cities but also in pre-dominantly Kurdish cities. However, further analysis demonstrates that the increase in AKP support among Kurdish voters was limited. Analysis shows that there were two major sources of the 8.6 percent increase in AKP votes in the November 2015 elections: ultra-nationalist MHP voters and Turkish voters who did not vote in the June 2015 elections. For further information, see KONDA Kasim'15 Barometresi, December 1，2015, https://konda.com.tr/wp-content/uploads/2017/03/ KONDA_1Kas\%C4\%B1m2015SandikveSecmenAnaliziRaporu.pdf: 41-6. 
is the best strategy for answering the research question. The third section summarizes the historical and political background, as this context is important for any discourse analysis. The findings section includes the comparative analysis of the discourse that the AKP used (1) before the June 2015 elections when the peace process was officially ongoing and (2) between the two general elections in 2015. The study ends with concluding remarks and suggestions for future research.

\section{Populism, ontological security, and securitization}

Populism is another contested term in social sciences. It is defined as a thin ideology, which considers society to be divided between two antagonistic groups - the pure people and the corrupt elite. ${ }^{5}$ It is also defined as a political strategy through which a personalistic leader seeks or exercises power by direct, unmediated, and uninstitutionalized support from the people. ${ }^{6}$ Others define populism as a political style that grows around a nativistic, personalistic, and culturally folksy pole. ${ }^{7}$ Populism has a chameleonic character. ${ }^{8}$ It takes a variety of forms, echoing different socio-cultural and cultural contexts. ${ }^{9}$ Populist movements, therefore, possess an ideological flexibility allowing them to capitalize on catch-all issues including religion, nationalism, and ethnicity, ${ }^{10}$ and to strategically shift their ideology in parallel to their goals. In communicating these ideological shifts to the people, populist movements use discourse, as spoken or written public statements are important in legitimating and animating political action in populist mobilization. ${ }^{11}$ Similarly, populist movements frequently use discourse to trigger perceptions of ontological insecurity, ${ }^{12}$ enabling them to generate public support.

Ontological security refers to a situation in which there is an absence of anxieties and dangers and when people's identities and autonomy are not in question. ${ }^{13}$ It is about one's need "to experience oneself as a whole continuous

5 Cas Mudde, "The Populist Zeitgeist," Government and Opposition 39, no. 3 (2004): 541-63.

6 Kurt Weyland, "Clarifying a Contested Concept: Populism in the Study of Latin American Politics," Comparative Politics 34, no. 1 (2001): 1-22.

7 Pierre Ostiguy and Kenneth Roberts, "Putting Trump in Comparative Perspective: Populism and the Politicization of the Cultural Low," The Brown Journal of World Affairs 23, no. 1 (2016): 25-50.

8 Paul Taggart, Populism (Buckingham: Open University Press, 2000).

9 Ibid.; Paul Taggart, "Populism and Representative Politics in Contemporary Europe," Journal of Political Ideologies 9, no. 3 (2004): 269-88.

10 Bilge Yabanci, "Populism as the Problem Child of Democracy: The AKP's Enduring Appeal and the Use of Meso-level Actors," Southeast European and Black Sea Studies 16, no. 4 (2016): 591-617.

11 Robert Jansen, "Populist Mobilization: A New Theoretical Approach to Populism," Sociological Theory 29, no. 2 (2011): 75-96.

12 Alexandra Homolar and Ronny Scholz, "The Power of Trump Speak: Populist Crisis Narratives and Ontological Security," Cambridge Review of International Relations 32, no. 3 (2019): 344-64.

13 Ronald Laing, The Divided Self: An Existential Study in Sanity and Madness (New York: Pelican, 1960). 
person in time." ${ }^{14}$ Ontological security derives from individuals' reliance on normality and predictability. ${ }^{15}$ Ontologically secure individuals have the confidence that they have "in the continuity of their self-identity and in the constancy of the surrounding social and material environment." ${ }^{\text {"16 }}$ Routine situations, therefore, constitute the core of ontological security. ${ }^{17}$ Where predictability of the routine is ruptured by societal discourses or external threats, the ontologically insecure citizen develops ${ }^{18}$ as routine situations are replaced by (perceptions of) critical situations. ${ }^{19}$ Hence, ontologically insecure citizens suffer from perceptions of the lack of a safe haven ${ }^{20}$ and are constantly in search of one.

Populist movements strategically draw upon people's need for ontological security to generate support in elections. ${ }^{21}$ Populist movements frame a situation as a crisis and define it as an existential threat, as crises serve to legitimize populist governance. ${ }^{22}$ By promoting a specific interpretation of a threat according to which groups are defined, ${ }^{23}$ populist movements use perceived or imagined threats and anxieties that the people experience against their culture, religion, and tradition. ${ }^{24}$ Construction of this crisis-setting helps populist movements "amplify voters' negative image of themselves, the country they live in and the challenges they face," which contributes to their electoral success. ${ }^{25}$ Where perceptions of threats do not exist, populist movements "perform the crisis" by acting as a trigger for crisis, ${ }^{26}$ thereby constructing gaps in people's sense of ontological security.

Election campaigns are unique moments where this populist strategy is crystallized. In their election campaigns, populist movements promote a specific reading of elections, in which each election is represented as a crisis moment at which the public must make a vital decision against some "existential threat." Once

14 Jennifer Mitzen, "Ontological Security in World Politics: State Identity and the Security Dilemma," European Journal of International Relations 12, no. 3 (2006): 341-70, 342.

15 Anthony Giddens, Modernity and Self-identity in the Late Modern Age (Cambridge: Polity Press, 1991).

16 Zeynep Gulsah Capan and Ayse Zarakol, 'Turkey's Ambivalent Self: Ontological Insecurity in 'Kemalism' versus 'Erdoganism',' Cambridge Review of International Affairs 32, no. 3 (2019): 263-82, 266.

17 Catarina Kinnvall, "Populism, Ontological Insecurity and Hindutva: Modi and the Masculinization of Indian Politics," Cambridge Review of International Affairs 32, no. 3 (2019): 283-302.

18 Stuart Croft, Securitizing Islam: Identity and the Search for Security (Cambridge: Cambridge University Press, 2012); Catarina Kinnvall, "Globalization and Religious Nationalism: The Search for Ontological Security," Political Psychology 25, no. 4 (2004): 741-67; Alanna Krolikowski, "State Personhood in Ontological Security Theories of International Relations and Chinese Nationalism: A Sceptical View," The Chinese Journal of International Politics 2, no. 1 (2008): 109-33.

19 Kinnvall, "Populism, Ontological Insecurity."

20 Ibid.

21 Ibid.; Homolar and Scholz, "The Power of Trump."

22 Muller, What is Populism.

23 Michel Foucault, Power/Knowledge (Brighton: Harvester, 1980).

24 Kinnvall, "Populism, Ontological Insecurity."

25 Homolar and Scholz, "The Power of Trump," 346.

26 Benjamin Moffitt, "How to Perform Crisis: A Model for Understanding the Key Role of Crisis in Contemporary Populism," Government and Opposition 50, no. 2 (2015): 189-217. 
the "referent" group accepts this discursive articulation, two developments follow. First, populists' articulation of the opposition takes hold and his/her supporters come to see the opposition candidate as an agent of ontological insecurity. Now, the opposition is not only a political opponent but also part of the enemy threatening the nation. Second, the use of extraordinary measures to prevent a possible victory of the opposition is seen as justified by the populist movement's referent group. This is because the opposition is not simply a political opponent but also an active agent of ontological insecurity, whose very existence threatens the nation.

The result of this populist strategy is the securitization of elections. Securitization constructs the "other" as an existential threat to a referent group, and calls for extraordinary measures to combat this threat. ${ }^{27}$ The act of securitization dramatizes an issue as vital and removes it from the sphere of mundane public debate. ${ }^{28}$ Securitization also causes the demands, grievances, and agendas of opposition groups to be labeled as seditious, ${ }^{29}$ paving the way for the demonization of the opposition. The following examples from the US, Hungary, and Venezuela demonstrate instances in which populist leaders securitized elections by triggering perceptions of ontological insecurity. As these examples demonstrate, populist leaders first define a crisis and then suggest that the elections are a critical turning point for the solution of the crisis. Frequently, a possible success of a political opponent is presented as an alternative scenario in which the crisis would exacerbate and threaten the nation, causing the securitization of the elections.

In his presidential campaign, Trump constructed an image of "America in crisis" to garner support. ${ }^{30}$ He demonized irregular migrants with labels such as criminals, rapists, or terrorists, ${ }^{31}$ thereby turning them into agents of ontological insecurity. He argued that every day the US border remains open, innocent Americans are killed. ${ }^{32}$ Trump suggested that while his opponent, Clinton, was soft on this threat, he would deal with irregular migrants decisively to protect the nation. In a similar vein, before the 2018 elections, Venezuela's Maduro argued that the country was in the midst of an economic war led by the US. ${ }^{33} \mathrm{He}$ cast his campaign

27 Barry Buzan, Ole Waever, and Jaap de Wilde, Security: A New Framework for Analysis (Boulder, CO: Lynne Rienner, 1998).

28 Alper Kaliber and Nathalie Tocci, "Civil Society and Transformation of Turkey's Kurdish Question," Security Dialogue 41, no. 2 (2010): 91-215.

29 Matthew Weiss, "From Constructive Engagement to Renewed Estrangement? Securitization and Turkey's Deteriorating Relations with Its Kurdish Minority," Turkish Studies 17, no. 4 (2016): 567-98.

30 Homolar and Scholz, "The Power of Trump."

31 Ibid.

32 NBC New York, "Trump: Open Border Cost American Lives," September 17, 2016, https://www.nbcnewyork. com/news/national-international/trump-speaks-at-anti-illegal-immigration-groups-conference/2038428/.

33 Reuters, "Maduro Vows Economic Change for Venezuela's 'Rebirth' before Vote," May 15, 2018, https:// www.reuters.com/article/us-venezuela-election/maduro-vows-economic-change-for-venezuelas-rebirthbefore-vote-idUSKCN1IG31S. 
as a battle against imperialist powers (and their domestic collaborators) determined to seize Venezuela's oil wealth. ${ }^{34}$ Similarly, Hungarian Prime Minister Orbán, before the 2018 elections, argued that Hungary's Christian culture was under threat from "millions of immigrants" and European leaders who wanted to let them in. ${ }^{35}$ Orbán suggested that the outcome of the elections would be decisive in the fight to defend the country against this threat.

\section{Historical and political background}

\section{The AKP and populism}

The AKP has been in power in Turkey since the November 2002 elections, making it the longest-ruling populist party in Europe. ${ }^{36}$ Some scholars argue that the AKP became populist in 2007 when threatened by the Kemalist elite and the uncompromising opposition, ${ }^{37}$ while others suggest that populist tones have been present in the AKP since its inception. ${ }^{38}$ Despite the disagreement over the origins of the AKP's populism, there is a consensus that the AKP displays features associated with populism, including (1) anti-institutionalism, ${ }^{39}$ (2) anti-establishment and anti-elite discourse, ${ }^{40}$ (3) antagonizing the people by

34 Reuters, "Venezuela's Maduro Defies Foreign Censure, Offers 'Prize' to Voters," May 3, 2018, https:// www.reuters.com/article/us-venezuela-election/venezuelas-maduro-defies-foreign-censure-offersprize-to-voters-idUSKBN1141KK.

35 "Prime Minister Viktor Orbán's Speech at the Final Fidesz Election Campaign Event," April 6, 2018, https://www.kormany.hu/en/the-prime-minister/the-prime-minister-s-speeches/prime-minister-viktororban-s-speech-at-the-final-fidesz-election-campaign-event.

36 Bilge Yabanci and Dane Taleski, "'Co-opting 'the Religion': How Ruling Populists in Turkey and Macedonia Sacralise the Majority," Religion, State \& Society 46, no. 3 (2018): 283-304.

37 Sakir Dincsahin, "A Symptomatic Analysis of the Justice and Development Party's Populism in Turkey, 2007-2010," Government and Opposition, 47, no. 4 (2010): 618-40; Orcun Selçuk, "Strong Presidents and Weak Institutions: Populism in Turkey, Venezuela and Ecuador," Southeast European and Black Sea Studies 16, no. 4 (2016): 571-89; Murat Somer, "Turkey: The Slippery Slope from Reformist to Revolutionary Polarization and Democratic Breakdown," ANNALS, AAPSS 681 (2019): 42-61.

38 Yabanci and Taleski, "'Co-opting 'the Religion'; Burak Bilgehan Ozpek and Nebahat Tanriverdi Yaşar, "Populism and Foreign Policy in Turkey under the AKP Rule," Turkish Studies 19, no. 2 (2018): 198-216.

39 Dincsahin, "A Symptomatic Analysis"; Hakki Tas, "Turkey - from Tutelary to Delegative Democracy," Third World Quarterly 36, no. 4 (2015): 776-91; Berk Esen and Sebnem Gumuscu, "Rising Competitive Authoritarianism in Turkey," Third World Quarterly 37, no. 9 (2016): 1581-1606; Antonino Castaldo, "Populism and Competitive Authoritarianism in Turkey," Southeast European and Black Sea Studies 18, no. 4 (2018): 467-84.

40 Ozpek and Tanriverdi Yaşar, "Populism and Foreign"; Yabanci, "Populism as the Problem"; Bill Park, "Populism and Islamism in Turkey," Turkish Studies 19, no. 2 (2018): 169-75; Tugce Erçetin and Emre Erdoğan, "How Turkey's Repetitive Elections Affected the Populist Tone in the Discourses of the Justice and Development Party Leaders," Philosophy \& Social Criticism 44, no. 4 (2018): 382-98. 
mobilizing existing divisions within society and demonizing the opposition, ${ }^{41}$ (4) an emphasis on national will and the association of national will with the leader, Erdoğan, ${ }^{42}$ and (5) mobilization of the masses for political goals. ${ }^{43}$

The AKP has used populism to hold on to power while ideological discourses voiced by its leadership demonstrated inconsistencies. ${ }^{44}$ It has adopted different ideologies and norms depending on the context and on its political goals. ${ }^{45}$ When founded in 2002, the AKP was advertised as a conservative-democratic political party that occupied the center-right of the political spectrum. ${ }^{46}$ Advertising itself as a conservative-democrat party enabled the AKP to adapt a thin understanding of Islam and to increase its appeal to the pious and liberal segments of society simultaneously. ${ }^{47}$ Therefore, Islamism, which some consider as an internal feature of the AKP, was used instrumentally by the AKP leadership. ${ }^{48}$ The AKP has used Islamism to stress the alien nature of the Kemalist elite in domestic politics. ${ }^{49}$ The AKP has also used Islam to counter challenges to its grip on power and to create cross-class and cross-ethnicity popular support for its rule ${ }^{50}$ For instance, the AKP drew strong support from conservative Kurds between 2002 and June 2015 by using an Islamic discourse. However, when the peace process between the armed Kurdistan Worker's Party (Partiya Karkeran Kurdistan, PKK) and the Turkish state officially ended in July 2015, the AKP shifted to a new discourse, which prioritized ethno-nationalism.

\section{The Kurdish question}

After the foundation of the Republic in 1923, aiming to build a nation-state built upon the ethno-cultural dominance of the Turkish identity, the state elite

41 Selçuk, "Strong Presidents"; Yabanci, "Populism as the Problem"; Erçetin and Erdoğan, "How Turkey's Repetitive"; Park, "Populism and Islamism"; Menderes Çınar, "Turkey's 'Western' or 'Muslim' Identity and the AKP's Civilization Discourse," Turkish Studies 19, no. 2 (2018): 176-97.; H. Bahadir Türk, "Populism as a Medium of Mass Communication': The Case of Recep Tayyip Erdoğan," International Area Studies Review 21, no. 2 (2018): 150-68.

42 Tas, "Turkey - from Tutelary"; Castaldo, "Populism and Competitive"; Selçuk, "Strong Presidents"; Yabanci, "Populism as the Problem"; Erçetin and Erdoğan, "How Turkey's Repetitive"; Türk,"Populism as a Medium."

43 Yabanci and Taleski, "Co-opting 'the Religion"'; Tas, "Turkey - from Tutelary"; Ozpek and Tanriverdi Yaşar, "Populism and Foreign Policy"; Yabanci, "Populism as the Problem"; Castaldo, "Populism and Competitive"; Türk, "Populism as a Medium."

44 Ozpek and Tanriverdi Yaşar, "Populism and Foreign Policy."

45 Ibid.

46 William Hale, "Christian Democracy and the AKP: Parallels and Contrasts," Turkish Studies 6, no. 2 (2005): 293-310.

47 Esen Kirdis and Amina Drmiheur, "The Rise of Populism? Comparing Incumbent Pro-lslamic Parties in Turkey and Morocco," Turkish Studies 17, no. 4 (2016): 599-617.

48 Çınar, "Turkey's 'Western' or 'Muslim' Identity."

49 Park, "Populism and Islamism."

50 Yabanci and Taleski, "Co-opting 'the Religion'." 
suppressed other ethnic identities. However, Kurds - unlike non-Muslim minorities - were considered to be assimilable into a Turkish identity. ${ }^{51}$ Thereafter, the state policy was to suppress public manifestations of Kurdish identity and attempt to assimilate Kurds into Turkish identity. ${ }^{52}$ The official policy suggested that Kurds were "mountain Turks" who forgot their Turkishness because of the multiethnic structure of the Ottoman Empire ${ }^{53}$ Kurds' cultural and political rights emanating from their identity was denied by the state ${ }^{54}$ Furthermore, the state considered expressions of Kurdish identity as a threat to the nation, resulting in the securitization of the Kurdish question, ${ }^{55}$ which also caused successive governments to avoid political means to deal with the issue. This meant the legitimization of the use of extraordinary measures to deal with the issue. ${ }^{56}$

The period after the 1980 military coup was important in shaping Kurds' relations to the state. After the coup, the state banned Kurdish in broadcasting, press, and public life. ${ }^{57}$ After the start of the armed conflict between the security forces and the PKK, the Turkish state declared a state of emergency in southeast Turkey, which lasted from 1987 to 2002, imposing heavy costs upon Kurds. Enforced disappearances, extrajudicial executions, and torture were commonplace in this period. ${ }^{58}$ Between 1980 and 2001, 1,353 people were forcibly disappeared by the security forces and thousands of murders have remained unsolved. 59

\section{The AKP and the Kurdish question}

Pragmatism, rather than reformism, has defined the AKP's treatment of the Kurds. ${ }^{60}$ Before the AKP, the mainstream political parties in Turkey could

51 Cenk Saracoglu, "Exclusive Recognition': The New Dimensions of the Question of Ethnicity and Nationalism in Turkey," Ethnic and Racial Studies 32, no. 4 (2019): 640-58.

52 Gunes Murat Tezcur, "When Democratization Radicalizes? The Kurdish Nationalist Movement in Turkey," Journal of Peace Research 47, no. 6 (2010): 775-89.

53 Senem Aslan, "Everyday Forms of State Power and the Kurds in the Early Turkish Republic," International Journal of Middle Eastern Studies 43, no. 1 (2011): 75-93.

54 Mesut Yegen, "The Kurdish Question in Turkish State Discourse," Journal of Contemporary History 34, no. 4 (1999): 555-68.

55 Burak Bilgehan Ozpek, "Paradigm Shift between Turkey and Kurds: From 'Clash of the Titans' to 'Game of Thrones'," Middle East Critique 27, no. 1 (2018): 43-60.

56 Kaliber and Tocci, "Civil Society"; Maurizio Geri, "From a History of Exclusion to the Securitization of the Kurdish Issue: A Step of Democratic Regression in Turkey," Muslim World Journal of Human Rights 13, no. 1 (2016): 25-43.

57 Zelal B. Kizilkan-Kisacik, "The Impact of the EU on Minority Rights: The Kurds as a Case," in The Kurdish Question in Turkey: New Perspectives on Violence, Representation, and Reconciliation, ed. Cengiz Gunes and Welat Zeydanlioglu (New York: Routledge, 2014), 205-24.

58 Ibid.

59 Özgur Sevgi Göral, Ayhan Işık, and Özlem Kaya, The Unspoken Truth: Enforced Disappearances. (İstanbul: Truth Justice Memory Center, 2013).

60 Ozpek, "Paradigm Shift." 
not develop approaches independent of the dominant security elite (i.e., the military). ${ }^{61}$ The AKP, however, tried to convince Kurds that their approach to the Kurdish question would be different from that of previous political parties. The 2002 AKP party program significantly diverged from the security paradigm, which had previously dominated state policy toward the Kurds. This program suggested that security-oriented approaches to the Kurdish question exacerbate the problem. Accordingly, one of the policies that the AKP suggested was an immediate abolishment of the state of emergency that had paralyzed the region since 1987. This program also argued that broadcasting and cultural activities in languages other than Turkish are not harmful to the nation. ${ }^{62}$ On the contrary, it would contribute to the solidarity and unity of the nation.

The AKP's approach toward the Kurds was hardly surprising given that its position was fragile due to the threat of the security establishment, which made the search for alliances a necessity for the AKP. The AKP, therefore, followed an agenda that would benefit potential allies such as conservatives, pro-EU circles, business associations, and Kurds. ${ }^{63}$ Furthermore, desecuritization of the Kurdish question would weaken the military tutelage over Turkish politics given that the military used its unique position in the fight against the PKK to hold on to political power. ${ }^{64}$ Hence, if the AKP were able to desecuritize the Kurdish question, the Kemalist elite would lose a significant cornerstone of its political power. This would provide the AKP with stronger prospects for survival against the Kemalist elite.

The AKP, therefore, was pragmatic in its treatment of the Kurds. Soon after coming to power in 2002, the AKP abolished the state of emergency covering Kurdish-populated cities. When in power, the AKP had continued criticizing the oppressive state tradition of the previous elite, which contributed to its image as a government that was different in terms of ethnic politics. ${ }^{65}$ The AKP introduced successive waves of reconciliation projects under different names, such as "Democratic Initiative" (Demokratik Acilim), "National Unity and Solidarity" (Milli Birlik ve Beraberlik), "the Oslo Process," and "the Peace Process." 66 Kurds found these attempts at reconciliation credible, ${ }^{67}$ as the AKP was not considered one of the political parties that symbolized the violence and ethnic discrimination of the 1990s.

61 Ibid.

62 "AK Parti Programı: Kalkinma ve Demokratiklesme Programı," February 11, 2002, https://acikerisim. tbmm.gov.tr/xmlui/bitstream/handle/11543/926/200205071.pdf?sequence=1\&isAllowed=y.

63 Ozpek, "Paradigm Shift."

64 Ibid.

65 Onur Gunay and Erdem Yoruk, "Governing Ethnic Unrest: Political Islam and the Kurdish Conflict in Turkey," New Perspectives on Turkey 61 (2019): 9-43.

66 Ibid.

67 For example, in the 2007 elections the AKP garnered 40 percent of the votes in Diyarbakir, making it the second largest political party in Diyarbakir after the pro-Kurdish Democratic Society Party. 


\section{Methodology}

Studying discourse is important because discourses are "institutionalized structures of meaning" that channel political thought and action in certain directions. ${ }^{68}$ Political leaders/movements use discourse to persuade the public of the necessity and appropriateness of a course of action. ${ }^{69}$ Discourse also allows political leaders/movements to establish a dominant narrative of an issue, setting the parameters of the discussion thereafter. ${ }^{70}$ These characteristics of discourse make it an important asset for populist movements, which rely on unmediated communication $^{71}$ and public statements ${ }^{72}$ rather than formal institutions in their communication with the people.

This study focuses on different discourses adopted by the AKP in two periods: the discourse between January 2013 and June 2015 and the discourse between June 2015 and November 2015. A keyword search was conducted for the AKP leadership's speeches and statements to the general public for these dates. As the aim was to find speeches and statements that revealed the AKP discourse about the Kurdish question, the peace process, and the double elections, keywords such as the elections (seçimler, Haziran seçimleri, Kasım seçimleri, önümüzdeki seçimler), the Kurdish question (Kürt sorunu, terör sorunu), the peace process (barış süreci, çözüm süreci), the People's Democracy Party (Halklarin Demokrasi Partisi, HDP), and the PKK were used to locate these particular speeches and statements. As a result of this search, fifty-seven speeches and statements by the AKP leadership on the Kurdish question, the peace process, and the elections were retrieved. Forty-four of these speeches belonged to Erdoğan. In the final step of the anal$y$ sis, these speeches and statements were read to determine recurring patterns and themes specific to these two different periods.

\section{Findings}

The comparative analysis revealed the triggers that the AKP used to build perceptions of ontological insecurity and to securitize the November 2015 elections. The analysis revealed that the AKP discourse between January 2013 and June 2015 aimed to desecuritize the Kurdish question. Analysis

68 Vivian Schmidt, "Discursive Institutionalism: The Explanatory Power of Ideas and Discourse," Annual Review of Political Science, no. 11 (2008): 303-26.

69 Ibid

70 Joshua W. Busby, "Narrative and the Making of US National Security" International Politics Review 4, no. 2 (2016): 108-11.

71 Weyland, "Clarifying a Contested Concept."

72 Jansen, "Populist Mobilization." 
demonstrated that, after the disappointment of the June 2015 elections, the AKP leadership started using a new discourse. The new AKP discourse between the two general elections included four core elements allowing them to build ontological insecurities and securitize the snap elections: (1) prioritization of the existential threats against the nation and resecuritization of the Kurdish question, (2) adoption of Turkish nationalism, (3) demonization of the HDP and equating it with terrorism, and (4) equating the AKP's victory in snap elections to the only way out of "chaos."

\section{The peace process: January 2013-June 2015}

In December 2012, Erdoğan announced that negotiations between the imprisoned PKK leader Öcalan and the Turkish state were ongoing. ${ }^{73}$ The symbolic start of the peace process was the Kurdish New Year (Newroz) celebrations on March 21, 2013, when Öcalan's letter on the peace process was read to more than a million people in Diyarbakir. ${ }^{74}$ This process was accompanied by the AKP's attempts to desecuritize the Kurdish question. For example, the government urged the establishment of the Committee of the Wise People (Akil Insanlar Heyeti), which was a sixty-three-person committee whose members had been chosen from among intellectuals, civil society activists, academics, and artists. ${ }^{75}$ The mission of this committee was to convince the public of the viability of a peaceful solution to the Kurdish question.

The AKP also used discourse to desecuritize the Kurdish question during the same period. In a well-known speech in 2013, Erdoğan argued that:

Those claiming that their race, tribe or clan is superior to others are in the same path with the devil. [...] We are all members of the same nation in the Turkish Republic. In this conceptualization of the nation, there is the Turk; there is the Kurd; there is the Laz; there is the Circassian. [...] Those promoting ethnic nationalism are in deviance and in malice. They are in sedition. With the permission of God, we are going to be in one in solidarity, alive and strong as we have been for thousands of years. [...] During this [peace] process, nobody should confront us with Kurdishness or Turkishness. We are a government, which trample[s] on any kind of nationalism. ${ }^{76}$

73 Cemal Ozkahraman, "Failure of Peace Talks between Turkey and the PKK: Victim of Traditional Policy or of Geopolitical Shifts in the Middle East?" Contemporary Review of the Middle East 4, no. 1 (2017): $50-66$.

74 Ibid.

75 Hürriyet, "Iste Akil Insanlar Heyeti," April 4, 2013, https://www.hurriyet.com.tr/gundem/iste-akilinsanlar-heyeti-22957853.

76 Hürriyet, "Erdoğan: Milliyetcilik Ayak Altinda," February 18, 2013, https://www.hurriyet.com.tr/ gundem/erdogan-milliyetcilik-ayak-altinda-22621388. 
This speech was significant at different levels. First, Erdoğan used inclusive language assigning the same level of importance to different ethnic groups in Turkey. This was in contrast to the Republican elite, who emphasized the primacy of Turkish identity over other ethnic identities. ${ }^{77}$ Second, Erdoğan discredited "ethnic nationalism," which had contributed to the securitization of the Kurdish question in the past. Third, he referred to an Islamic argument, asserting that divisions based on ethnic identities are harmful to the unity of Muslims. According to this argument, the Islamic brotherhood of Muslims (ummah) should prevail over ethnic parochialisms. This demonstrates that during the peace process, Erdoğan's inclusive discourse toward the Kurds was based on Islamism. ${ }^{78}$

On another occasion, Erdoğan built on the same discourse when talking about the peace process:

We are the only political party in this country, which would not allow discrimination based on ethnic identities. Kurds, Lazs, Circassians, Georghians, Abhazs, Romans and Pomaks, are my brothers as much as Turks. [...] In contrast to the CHP [The Republican People's Party (Cumburiyet Halk Partisi, CHP)], we think that discriminative nationalism is doing unjust to this nation's history. In contrast to the MHP [Nationalist Action Party (Milliyetçi Hareket Partisi)], we will never encourage the kind of nationalism, which is tainted by the language of hatred, anger, division and discrimination. ${ }^{79}$

This speech, in addition to rejecting ethnic nationalism in favor of inclusive nationalism, set a tone aiming to differentiate the AKP from the opposition in its approach to the Kurdish question. Erdoğan suggested that while the other major political parties promote exclusionary nationalism, the AKP does not prioritize one ethnic group over others. This discourse was part of the strategy suggesting that the AKP is different from previous political parties, which created the Kurdish question. Other leading names of the AKP highlighted the same point about the opposition parties. They blamed the opposition parties for Kurds' problems and argued that these parties aggravated the Kurdish question. A prominent AKP MP argued that:

77 Ozkahraman, "Failure of Peace."

78 During the campaign process leading to the June 2015 elections, in predominantly Kurdish cities Erdoğan campaigned with a Kurdish-translated Quran in his hand. In Kurdish-populated cities, Erdoğan emphasized the brotherhood of Muslims in his speeches.

79 Sabah, "Gerekirse Baldiran Zehiri Icerim," February 26, 2013, https:/www.sabah.com.tr/gundem/ 2013/02/26/gerekirse-baldiran-zehri-icerim. 
Both CHP and MHP live on the same problem [the Kurdish question]. The $\mathrm{CHP}$ is the cause of the problem and the MHP exacerbates it. The CHP's monist and fascist mindset is the cause of the Kurdish question in Turkey. [...] The MHP, with its nationalism based on the bloods of martyred soldiers, aggravated Kurdish nationalism and caused the PKK to thrive. ${ }^{80}$

Therefore, during the peace process, the AKP discourse aimed to desecuritize the Kurdish question. The discourse was inclusionary toward the Kurdish ethnic identity and exclusionary toward the opposition, as they were held responsible for the Kurdish question.

The end of the peace process and the snap general elections: June 2015 and November 2015

In December 2014, the pro-Kurdish HDP co-leader, Demirtaş, explained that unlike previous pro-Kurdish parties the HDP candidates would enter the elections under the HDP party ticket instead of as independent candidates. ${ }^{81}$ This decision was risky, as (1) there were doubts about the HDP's ability to pass the 10 percent national threshold, and (2) it could alienate the AKP if the HDP were to cause a major decline in the number of AKP MPs in the parliament. ${ }^{82}$ Indeed, in the June 2015 elections the AKP won 40.9 percent of the votes, a result that prevented the establishment of an AKP single-party government. This outcome was unexpected for the AKP leadership, as they had anticipated that the peace process would boost their votes among Kurds. The pro-Kurdish HDP garnered 13.1 percent of the votes. Furthermore, the HDP was able to increase its votes not only in predominantly Kurdish cities but also in the metropolises of western Turkey. ${ }^{83}$ Only one day after the elections, Deputy Prime Minister Akdoğan revealed their discontent with the HDP's role in the AKP's poor standing in the elections. He said: "From this point forward, the HDP can only shoot a movie about the peace process." ${ }^{\text {. }}$

80 Haber 7, "Metiner'den CHP ve MHP'ye Cok Agir Suclama," May 21, 2013, http://www.haber7.com/ roportaj/haber/1028918-metinerden-chp-ve-mhpye-cok-agir-suclama.

81 Milliyet, "Secime Parti Olarak Girecegiz," December 15, 2014, https://www.milliyet.com.tr/gundem/ secime-parti-olarak-girecegiz-1984367.

82 The electoral system in Turkey is d'Hondt with a 10 percent election threshold. This system provides advantages for larger parties, while smaller parties are in a disadvantageous position. However, unlike with other smaller parties in Turkey, the HDP's vote is concentrated in the southeast and the east of Turkey, allowing the HDP to win a larger number of MPs once passing the threshold. In this scenario, the second largest party in these two regions (i.e., the AKP) would lose seats, which would go to the AKP if the HDP were to enter the elections with independent candidates.

83 Gunay and Yoruk, "Governing Ethnic Unrest."

84 Hürriyet, "Yalcin Akdogan: HDP Bundan Sonra Cozum Surecinin Ancak Filmini Yapar," June 8, 2015, https://www.hurriyet.com.tr/gundem/yalcin-akdogan-hdp-bundan-sonra-cozum-surecinin-ancakfilmini-yapar-29227700. 
His statement hinted that the AKP was either planning to exclude the HDP from the peace process or completely close the door on the peace process. Unsurprisingly, the peace process officially ended on July 24, 2015 after the Turkish army bombarded the PKK positions in Qandil Mountain. ${ }^{85}$

Research points to several reasons for the failure of the peace process and the resecuritization of the Kurdish question. These include the de-Europeanization of Turkey and its deteriorating relations with the EU, the Syrian civil war and the presence of autonomous Kurdish cantons in northern Syria, the emergence of a new generation of Kurdish politicians who were not willing to support Erdoğan's agenda, and the instrumentalization of the peace process by the AKP government. ${ }^{86}$ Indeed, a major weakness of the peace process was the fact that the AKP tied the peace process to its success in the elections as well as the Kurdish movement's support for Erdoğan's agenda for a presidential system. ${ }^{87}$ Erdoğan emphasized the importance of a strong incumbent party with $400 \mathrm{MPs}^{88}$ to the success of the peace process. ${ }^{89}$ When the new generation of Kurdish politicians declined to extend support for his political agenda, ${ }^{90}$ Erdoğan's attitudes toward the peace process started to change. ${ }^{91}$ This is why the HDP's December 2014 declaration that the HDP candidates would enter the elections with the party ticket was an

85 The pretext for ending the peace process was the assassination of two police officers in Ceylanpinar, Urfa on July 22, 2015. However, the senior PKK leadership refused the responsibility for this assassination. See, BBC, "Kandil: Cozum Sureci Tekrar Baslatilabilir, Zor Degil," July 29, 2015, https://www.bbc.com/turkce/ haberler/2015/07/150728_kandil_roportaj. Though nine people were arrested after the assassination, all of them were later acquitted. See, Cumhuriyet, "Cozum Surecini Bitiren Ceylanpinar'daki Iki Polisin Cinayeti Davasi da Beraatle Sonuclandi," March 1, 2018, http://www.cumhuriyet.com.tr/haber/cozumsurecini-bitiren-ceylanpinardaki-iki-polisin-cinayeti-davasi-da-beraatle-sonuclandi-935930.

86 Gunay and Yoruk, "Governing Ethnic Unrest"; Ozpek, "Paradigm Shift"; Burak Bilgehan Ozpek, "The State's Changing Role Regarding the Kurdish Question of Turkey: From Consistent Tutelage to Volatile Securitization," Alternatives: Global, Local, Political 44, no. 1 (2019): 35-49; Pavel Shlykov, "Peace Process, International Organizations and the 'Kurdish Question'," in The Palgrave Handbook of Global Approaches to Peace, ed. Aigul Kulnazarova and Vesselin Poposki (Cham: Palgrave Macmillan, 2019), 519-44.; Weiss, "From Constructive Engagement."

87 Weiss, "From Constructive Engagement"; Ozpek, "The State's Changing Role."

88 This number would allow the AKP to control over two-thirds of the Turkish parliament. Accordingly, the AKP could change the constitution in line with a presidential system without needing a referendum or the support of opposition parties.

89 Ozpek, "The State's Changing Role"; Milliyet, "Erdoğan: 400 Milletvekili Lazim," February 2, 2015, https://www.milliyet.com.tr/siyaset/erdogan-400-milletvekili-lazim-2009741.

90 In March 2017 the HDP co-leader Demirtaş made a speech in which he repeatedly stated, "We will not let you [Erdoğan] become the president." While the speech was met with enthusiasm among the opposition, the reaction of the AKP to this statement was swift. Five days after the peace process ended, Deputy Prime Minister Akdoğan argued that Demirtaş' statement was an open provocation, which started the downward trend in the peace process. See, Cumhuriyet, "Akdoğan itiraf etti: Erdoğan tahrik oldu," July 29, 2015. http://www.cumhuriyet.com.tr/haber/akdogan-itiraf-ettierdogan-tahrik-oldu-333227.

91 Weiss, "From Constructive Engagement." 
important turning point. This claim is also supported by the fact that though the peace process was officially ongoing in 2015, no visible progress was made toward peace after the HDP's declaration of entering the elections on the party ticket. This was despite the fact that a major step was taken toward peace with the Dolmabahçe Consensus. Later, Erdoğan even argued that he had never endorsed the Dolmabahçe Consensus, causing great controversy even in his own ranks. While this and the other factors listed above are important for understanding the collapse of the peace process, this study argues that the AKP's desire to reverse their electoral defeat in the June 2015 elections is another factor that needs attention. ${ }^{92}$

The outcome of the June 2015 elections revealed the collapse of the AKP's strategy in the elections. ${ }^{93}$ Far from obtaining the supermajority that would allow Erdoğan to implement his agenda, the AKP lost its majority in the parliament. Not only the HDP but also the ultra-nationalist MHP, which was highly critical of the peace process, increased its votes at the expense of the AKP. Rather than accepting the election results and seeking a coalition government with other political parties in the parliament, the AKP, under Erdoğan's guidance, implemented a series of moves to reverse this electoral defeat. First, Erdoğan obstructed Prime Minister Davutoğlu's attempts to form a coalition government with the CHP or the MHP ${ }^{94}$ Second, he forced snap elections scheduled for November 2015. Third, the AKP leadership triggered perceptions of ontological insecurities, enabling the AKP to securitize the November elections.

As noted earlier, populists, in line with the changing political and social context, shift their discourse strategically. ${ }^{95}$ In their discursive engagement with the voters, populists refer to perceived or imagined threats to exploit people's need for ontological security, ${ }^{96}$ which in turn increases the electoral support for populists. ${ }^{97}$ Where the perception of a threat does not exist, populists

92 Though this study focuses on the AKP's motivation to reverse the outcome of the June 2015 elections in explaining the failure of the peace process, it does not argue that the electoral dimension was the only reason causing the collapse of the peace process. Other factors such as the diminishing of the EU anchor and the spillover from the Syrian war were among the other reasons that contributed to the failure of the peace process. Research, for instance, argued that the emergence of a proto-Kurdish state in northern Syria cast a long shadow on the Turkish state's relations with own Kurdish citizens as well as on the peace process, eventually leading to the collapse of the peace process. For an example such studies, see Weiss, "From Constructive Engagement."

93 Ozpek, "The State's Changing Role."

94 One must note that opposition parties were also polarized among themselves, making the task easier for Erdoğan. The MHP rejected any offer that implied cooperation with the HDP. Therefore, a coalition government established by opposition parties was never on the table.

95 Taggart, Populism; Taggart, "Populism and Representative Politics."

96 Homolar and Scholz, "The Power of Trump."

97 Ibid. 
trigger the crisis ${ }^{98}$ and perceptions of ontological insecurity. In 2015, Turkish public opinion was already receptive to a shift toward a discourse prioritizing ontological insecurities. Turkey was shaken by three major terrorist attacks perpetrated by the Islamic State (ISIS) in 2015. In June, an ISIS attack at the HDP meeting in Diyarbakir killed five people. In July, another ISIS attack in Suruç killed thirty-three people, who were mostly leftist university students. In the bloodiest terrorist attack in Turkish history, ISIS killed 109 peace protesters in Ankara in October 2015.

In this political and social context, the AKP used the Kurdish question to trigger people's perceptions of ontological insecurity and securitize the elections. The fact that the AKP centered its discourse on the Kurdish question after June 2015, while overlooking the ISIS threat, stemmed from two reasons. First, the conflictual history between Kurds and the Turkish state as well as the forced migration of Kurds caused Turks to establish an exclusionary and antagonistic relationship with Kurds, ${ }^{99}$ while the ISIS threat in Turkey did not carry the same historical baggage. Accordingly, the Turkish people were more receptive to a discourse that emphasized the Kurdish question as an existential threat to the nation. Second, the AKP was able to couple the PKK with the HDP in the elections, while the AKP could not implement a similar strategy for the ISIS threat. The Kurdish question, therefore, was more suitable for securitizing the elections because, in its election campaign, the AKP was able to present the HDP as an extension of the PKK.

The AKP officially ended the peace process on July 24, 2015, after it became clear that the peace process did not help the AKP's electoral standing. ${ }^{100}$ Thereafter, the new AKP discourse prioritized ethnic nationalism and ontological insecurity triggers, which would allow the AKP to maintain its hegemony. ${ }^{101}$ This new discourse aimed to develop a new mode of ethnic nationalism whereby overt hostility against the Kurdish opposition became the major strategy for garnering Turkish nationalist support. ${ }^{102}$ The new discourse included four core elements allowing it to build ontological insecurities and then securitize the November elections: (1) prioritization of the existential threats against the nation and resecuritization of the Kurdish question, (2) adoption of Turkish nationalism, (3) demonization of the HDP and equating it with terrorism, and (4) equating the AKP's victory in snap elections with the only way out of the "chaos."

98 Moffitt, "How to Perform."

99 Saracoglu, "Exclusive Recognition'."

100 Shlykov, "Peace Process."

101 O'Driscoll and Baser, "Independence Referendums."

102 Gunay and Yoruk, "Governing Ethnic Unrest." 
While the AKP discourse before the June elections emphasized normalization, a core element of the AKP discourse after the June 2015 elections was the prioritization of the existential threats against the nation and resecuritization of the Kurdish question. In a statement in September 2015, Erdoğan argued that those who wanted him to lose did not care about Turkey. He said that nobody should focus on such issues while "Turkey is fighting against the PKK terrorism, DHKP-C terrorism, ISIS threat and the treasons of parallel state organization [Gulenists]." 103 In September 2015, Erdoğan and Prime Minister Davutoğlu joined a meeting named "One voice against terror." In this meeting, both Erdoğan and Davutoğlu emphasized the terrorist threats that the nation was facing. ${ }^{104}$ The AKP leadership also resecuritized the Kurdish question by prioritizing the armed struggle against the PKK while political solutions were taken off the table. He argued:

We are will continue our fight until terrorist organizations are no more threats to our country, until those weapons are laid down and buried. [...] We will continue our fight until concrete is poured [on weapons] and not one terrorist remains within our borders. [...] We never considered the peace process as a means to legitimize terrorism or give them elbowroom. [...] Unfortunately, they [the PKK and the HDP] did not want to understand this. Therefore, the peace process is now in the refrigerator. ${ }^{105}$

Public opinion polls demonstrated the success of the new discourse. An IPSOS survey found that while in May 2015 only 14 percent of the Turkish population considered the peace process/terrorism to be the most important problem in Turkey, this figure increased to 47 percent in August 2015 and a staggering 72 percent in September 2015. ${ }^{106}$ One should note that the increase in the percentage of people considering the peace process/terrorism to be the most important problem occurred before the October 2015 bombings in Ankara - the biggest terrorist attack in Turkish history. This increase also occurred before the start of trench warfare between the state security forces and the PKK, which heavily affected Kurdish-populated cities

103 Turkiye, "Cumhurbaskani Erdoğan: Demokrasi Degil Ihanet Sorunu," September 9, 2015, https:// www.turkiyegazetesi.com.tr/gundem/304179.aspx.

104 NTV, "Yenikapi'da "Terore Karsi Tek Ses" Mitingi," September 20, 2015, https://www.ntv.com.tr/ turkiye/yenikapida-terore-karsi-miting,hj4aln45CEyO19ak-XaEJg.

105 Turkiye, "Erdoğan, Bundan Sonra Cozum Sureci Buzdolabina Kaldirilmistir," August 11, 2015, https:// www.turkiyegazetesi.com.tr/politika/296110.aspx.

106 Hürriyet, "IPSOS Arastirmasindan Carpici Sonuclar," September 30, 2015, https://www.hurriyet.com. tr/gundem/ipsos-arastirmasindan-carpici-sonuclar-30196041. 
in Turkey. Therefore, the new AKP discourse had started to shape public opinion in Turkey well before these bloody events.

The second element of the new discourse was the adoption of a nationalist discourse. ${ }^{107}$ To get nationalist support, the AKP leadership followed a more nationalist and militarist agenda ${ }^{108}$ Tuğrul Türkeş, an MP from the ultranationalist MHP, was invited to be a minister in the interim government in August 2015, and later resigned from the MHP to join the AKP ranks. ${ }^{109}$ Erdoğan also adopted a nationalist terminology in the course of the campaign for the snap elections. On several occasions he asked the people to send "550 native and national MPs to the parliament." ${ }^{110}$ In a speech in October, nationalist overtones were strong. Erdoğan argued:

We have only one flag; do we have another one? Sadly, people carrying a second flag [the HDP] can get votes in this country. [...] Without any shame they claim that they have no problem with the flag. I don't know if you [the HDP] have a problem with the flag but I know that you have a problem with the Turkish flag. [...] You are against even our national anthem because you could never be [a part of] the one nation; [a part of] the one flag, and [a part of] the one homeland. You have always sided with separatism. ${ }^{111}$

In another speech, Erdoğan argued that the nation was threatened by terrorism. He argued that the nation would neutralize these threats by uniting around the principle of "one nation, one flag, one homeland, and one state."112

The third core element of the AKP discourse was the demonization of the HDP and equating it with the PKK. In one of his speeches, while referring to the HDP, Erdoğan asked:

Is shielding terrorism one of the duties of a political party? [ . . ] Is politics about protecting terrorists and targeting security forces with lies, smears and distortions? [ . . ]. 1 November [elections] should be a milestone; it should be a rebirth. With this rebirth, in this country God willing, we are going to bury terrorism under the ground. ${ }^{113}$

107 Ibid.; Ozpek, "Paradigm Shift."

108 Ozpek, "Paradigm Shift."

109 Weiss, "From Constructive Engagement."

110 BBC, "Erdoğan: 1 Kasim'da Meclis'e Yerli ve Milli 550 Milletvekili Yollayin," September 20, 2015, https://www.bbc.com/turkce/haberler/2015/09/150920_istanbul_miting.

111 Turkiye Cumhuriyeti Cumhurbaskanligi, "13. Muhtarlar Bulusmasi'nda Yaptiklari Konusma," October 26, 2015, https://www.tccb.gov.tr/konusmalar/353/35910/13-muhtarlar-toplantisinda-yaptiklari-konusma.

112 Anadolu Ajansi, "Milletimiz Ustesinden Gelecek," August 29, 2015, https://www.aa.com.tr/tr/politika/ milletimiz-ustesinden-gelecek/5461.

113 Haberturk, "Cumhurbaskani Erdoğan'dan HDP'ye Agir Sozler," September 17, 2015, https://www. haberturk.com/video/haber/izle/cumhurbaskani-erdogandan-hdpye-agir-sozler/149698. 
In another speech in October 2015, Erdoğan argued:

Those who talk about peace when they go to the west are the same people who bomb the hospital in Şemdinli, police stations, mosques, and the airport. On the one hand, you talk about peace and on the other hand, you terrorize everywhere in collaboration with the PKK, which you [the HDP] rely on. I address my nation and the people of the region [Kurdish-populated cities], if you are not going to teach a lesson to those [the HDP] who rely on the terrorist organization in 1 November elections, when are you going to teach them a lesson? ${ }^{14}$

This element of the new discourse enabled the AKP to delegitimize the HDP as a legal actor of Turkish politics. It created an atmosphere in which the HDP, which was presented as an extension of the PKK, was equated with terrorism. A possible HDP success in the November elections was presented as a source of ontological insecurity for the Turkish people. An AKP MP manifested this feeling in the following words: "I think if the HDP passes the threshold or gets $14-15 \%$ as claimed, it will cause more violence." 115 Hence, the November elections were securitized, as the possible success of the HDP was displayed as a "security threat" and defeating the HDP (thereby, the PKK) was tied to the outcome of this election. ${ }^{116}$

The last element of the AKP discourse was to equate the success of the AKP in the snap general elections with the only way out of chaos. The campaign slogan for the November 2015 elections was "We are walking towards stability." Accordingly, themes such as stability, tranquility, and "the way out of chaos" were repeatedly emphasized throughout the campaign. It was argued that only the AKP single-party government could deliver these public goods, whereas other election outcomes would only exacerbate the security situation in Turkey. Prime Minister Davutoğlu argued that:

1 November 2015 will be the path to hope, not to despair or anxiety. Turkey will say "trust" and "stability" again. It will say no to chaos. Turkey will say "No" to darkness and unknown and "Yes" to justice and development. ${ }^{117}$

114 Sabah, "Cumhurbaskani Erdoğan: Oleceksek Adam Gibi Olelim," October 26, 2015, https://www. sabah.com.tr/video/turkiye/cumhurbaskani-erdogan-oleceksek-adam-gibi-olelim.

115 Post Medya, "AKP'li Vekil Orhan Miroglu'ndan Skandal Tehdit: HDP Baraji Gecerse Catisma Artar!" September 20, 2015, https://www.youtube.com/watch?v=qFphsZ6KKyQ.

116 Focus groups held with Turkish nationalist voters who shifted their votes to the AKP in the November elections revealed the success of the strategy of securitizing the elections. The informants unanimously emphasized the importance of ending chaos and terror in their decision to vote for the AKP in the snap elections. They argued that they were motivated by the AKP's willingness to use an "iron fist" against the Kurdish movement. For the focus groups, see Gunay and Yoruk, "Governing Ethnic Unrest," 35-8.

117 Anadolu Ajansi, "Turkiye, 1 Kasim'da Guven ve Istikrar Diyecek," October 24, 2015, https://www.aa. com.tr/tr/politika/turkiye-1-kasimda-guven-ve-istikrar-diyecek/455476. 
This element of the discourse was widely circulated at the local level by AKP representatives. For instance, the AKP candidate in Van argued that:

One cannot talk about stability, tranquility and peace where the AKP does not exist $[\ldots]$ When there is the AKP, there is tranquility, stability, and peace. Think about the opposite. There is none of these without the AKP. ${ }^{118}$

This core element of the new discourse signaled to the citizens that only the AKP single-party government could end the people's ontological insecurities. While the opposition parties and coalition governments were associated with instability, terrorism, and lack of a resolve to fight existential threats, it was argued that the AKP had the determination and power to bring about stability and end all existential threats, which were caused by the loss of the AKP single-party government in the June 2015 elections.

\section{Conclusion}

Populist movements thrive in extraordinary times. They use perceptions of crisis to convince the people that their message is important and urgent. ${ }^{119}$ They "perform the crisis"120 to inculcate a perception of an existential threat - to go beyond the limits of mundane politics and convince their audience to vote for them. A particular strategy to go beyond mundane politics is creating perceptions of ontological insecurity that would lead to the securitization of the elections. This study suggested that one of the reasons for the AKP's ability to reverse the election results in less than five months was its ability to create perceptions of ontological insecurity and to securitize the elections by building upon people's ontological insecurity perceptions.

This study argued that the AKP's deliberate decision to use a new discourse enabled it to recover its losses in the November 2015 elections. The new discourse triggered perceptions of ontological insecurity by prioritizing threats against the nation and resecuritizing the Kurdish question. The HDP was portrayed as an extension of the PKK and an agent of ontological insecurity in the elections. The new discourse, therefore, securitized the snap general elections by equating the pro-Kurdish HDP with the PKK. Thereafter, the November 2015 elections were presented as extraordinary elections that could have dire consequences for the nation if the AKP were not victorious. This strategy worked well. In the words of a voter who shifted

118 IHA, "Ebubekir Kacmaz: AK Parti Iktidar Olmazsa Istikrar Olmaz," October 20, 2015, https://www.iha. com.tr/haber-ebubekir-kacmaz-ak-parti-iktidar-olmazsa-istikrar-olmaz-504976/.

119 Taggart, "Populism and Representative Politics."

120 Moffitt, "How to Perform." 
her vote to the AKP in the snap elections, "If I had voted for another party, this party would not have showed a governing style as stable as that of Erdoğan. I thought that other parties could not resolve the terror problem. The AKP did show stability for coping with terror."121

While this study focused on the Turkish case, there are lessons for other countries. For populist movements, every election is an opportunity to promote perceptions of threat that allegedly require immediate and extraordinary action. Trump's 2016 campaign in the US and the Johnson campaign in the UK in 2019 demonstrated how populists promote perceptions of urgency (e.g., "Get Brexit Done") and refer to existential threats (e.g,, migrants are rapists) to convince constituents that these elections are extraordinary elections requiring voters to make some crucial decisions. In other words, populist movements securitize elections by referring to elements that "threaten the nation" and require "decisive and extraordinary" action, which only the populist leader can deliver. These strategies, while benefiting populist movements, harm democracy, as securitization obstructs a meaningful discussion of political issues. Accordingly, one particular task awaiting proponents of democracy is to develop strategies that could prevent populist movements from hijacking the political agenda in general and the mainstream media in particular. This topic, however, is beyond the scope of this study and could be the focus of future studies.

\section{Funding}

This article has received funding from the European Union's Horizon 2020 research and innovation program under grant agreement No 822590. Any dissemination of results here presented reflects only the author's view. The agency is not responsible for any use that may be made of the information it contains.

\section{References}

"AK Parti Programı: Kalkinma ve Demokratiklesme Programı." February 11, 2002, https://acikerisim.tbmm. gov.tr/xmlui/bitstream/handle/11543/926/200205071.pdf?sequence=1\&isAllowed=y.

"Prime Minister Viktor Orbán's Speech at the Final Fidesz Election Campaign Event." April 6, 2018, https:// www.kormany.hu/en/the-prime-minister/the-prime-minister-s-speeches/prime-minister-viktororban-s-speech-at-the-final-fidesz-election-campaign-event.

Anadolu Ajansi. "Milletimiz Ustesinden Gelecek." August 29, 2015, https://www.aa.com.tr/tr/politika/ milletimiz-ustesinden-gelecek/5461.

_. "Turkiye, 1 Kasim'da Guven ve Istikrar Diyecek." October 24, 2015, https://www.aa.com.tr/tr/politika/ turkiye-1-kasimda-guven-ve-istikrar-diyecek/455476.

Aslan, Senem. "Everyday Forms of State Power and the Kurds in the Early Turkish Republic." International Journal of Middle Eastern Studies 43, no. 1 (2011): 75-93.

121 Gunay and Yoruk, "Governing Ethnic Unrest," 36. 
BBC. “Kandil: Cozum Sureci Tekrar Baslatilabilir, Zor Degil.” July 29, 2015, https://www.bbc.com/turkce/ haberler/2015/07/150728_kandil_roportaj.

. "Erdoğan: 1 Kasim'da Meclis'e Yerli ve Milli 550 Milletvekili Yollayin." September 20, 2015, https:// www.bbc.com/turkce/haberler/2015/09/150920_istanbul_miting.

Busby, Joshua. "Narrative and the Making of US National Security." International Politics Review 4, no. 2 (2016): 108-11.

Buzan, Barry, Ole Waever, and Jaap de Wilde. Security: A New Framework for Analysis. Boulder, CO: Lynne Rienner, 1998.

Capan, Zeynep Gulsah and Ayse Zarakol. "Turkey's Ambivalent Self: Ontological Insecurity in 'Kemalism' versus 'Erdoganism'." Cambridge Review of International Affairs 32, no. 3 (2019): 263-82.

Castaldo, Antonino. "Populism and Competitive Authoritarianism in Turkey." Southeast European and Black Sea Studies 18, no. 4 (2018): 467-84.

Çınar, Menderes. “Turkey's 'Western' or 'Muslim' Identity and the AKP's Civilization Discourse.” Turkish Studies 19, no. 2 (2018): 176-97.

Croft, Stuart. Securitizing Islam: Identity and the Search for Security. Cambridge: Cambridge University Press, 2012.

Cumhuriyet. "Akdoğan itiraf etti: Erdoğan tahrik oldu." July 29, 2015. http://www.cumhuriyet.com.tr/ haber/akdogan-itiraf-etti-erdogan-tahrik-oldu-333227.

_. "Cozum Surecini Bitiren Ceylanpinar'daki Iki Polisin Cinayeti Davasi da Beraatle Sonuclandi." March 1, 2018, http://www.cumhuriyet.com.tr/haber/cozum-surecini-bitiren-ceylanpinardaki-iki-polisincinayeti-davasi-da-beraatle-sonuclandi-935930.

Dincsahin, Sakir. "A Symptomatic Analysis of the Justice and Development Party's Populism in Turkey, 2007-2010." Government and Opposition 47, no. 4 (2010): 618-40.

Erçetin, Tugce and Emre Erdoğan. "How Turkey's Repetitive Elections Affected the Populist Tone in the Discourses of the Justice and Development Party Leaders." Philosophy \& Social Criticism 44, no. 4 (2018): 382-98.

Esen, Berk and Gumuscu, Sebnem. "Rising Competitive Authoritarianism in Turkey." Third World Quarterly 37, no. 9 (2016): 1581-606.

Foucault, Michel, Power/Knowledge. Brighton: Harvester, 1980.

Geri, Maurizio. "From a History of Exclusion to the Securitization of the Kurdish Issue: A Step of Democratic Regression in Turkey." Muslim World Journal of Human Rights 13, no. 1 (2016): 25-43.

Giddens, Anthony. Modernity and Self-Identity in the Late Modern Age. Cambridge: Polity Press, 1991.

Göral, Özgur Sevgi, Ayhan Işık, and Özlem Kaya, The Unspoken Truth: Enforced Disappearances. İstanbul: Truth-Justice Memory Center, 2013.

Gunay, Onur and Erdem Yoruk. "Governing Ethnic Unrest: Political Islam and the Kurdish Conflict in Turkey." New Perspectives on Turkey 61 (2019): 9-43.

Haber 7. "Metiner'den CHP ve MHP'ye Cok Agir Suclama." May 21, 2013, http://www.haber7.com/ roportaj/haber/1028918-metinerden-chp-ve-mhpye-cok-agir-suclama.

Haberturk. "Cumhurbaskani Erdoğan'dan HDP'ye Agir Sozler." September 17, 2015, https://www. haberturk.com/video/haber/izle/cumhurbaskani-erdogandan-hdpye-agir-sozler/149698.

Hale, William. "Christian Democracy and the AKP: Parallels and Contrasts." Turkish Studies 6, no. 2 (2005): 293-310.

Homolar, Alexandra and Ronny Scholz. "The Power of Trump Speak: Populist Crisis Narratives and Ontological Security." Cambridge Review of International Relations 32, no. 3 (2019): 344-64.

Hürriyet. "Erdoğan: Milliyetcilik Ayak Altinda." February 18, 2013, https://www.hurriyet.com.tr/gundem/ erdogan-milliyetcilik-ayak-altinda-22621388.

—. "Iste Akil Insanlar Heyeti." April 4, 2013, https://www.hurriyet.com.tr/gundem/iste-akil-insanlarheyeti-22957853.

__. "Yalcin Akdogan: HDP Bundan Sonra Cozum Surecinin Ancak Filmini Yapar." June 8, 2015, https:// www.hurriyet.com.tr/gundem/yalcin-akdogan-hdp-bundan-sonra-cozum-surecinin-ancak-filminiyapar-29227700. 
. "IPSOS Arastirmasindan Carpici Sonuclar." September 30, 2015, https://www.hurriyet.com.tr/ gundem/ipsos-arastirmasindan-carpici-sonuclar-30196041.

IHA. "Ebubekir Kacmaz: AK Parti Iktidar Olmazsa Istikrar Olmaz." October 20, 2015, https://www.iha.com. tr/haber-ebubekir-kacmaz-ak-parti-iktidar-olmazsa-istikrar-olmaz-504976/.

Jansen, Robert. "Populist Mobilization: A New Theoretical Approach to Populism." Sociological Theory 29, no. 2 (2011): 75-96.

Kaliber, Alper and Nathalie Tocci. "Civil Society and Transformation of Turkey's Kurdish Question." Security Dialogue 41, no. 2 (2010): 91-215.

Kinnvall, Catarina. "Globalization and Religious Nationalism: The Search for Ontological Security." Political Psychology 25, no. 4 (2004): 741-67.

_. "Populism, Ontological Insecurity and Hindutva: Modi and the Masculinization of Indian Politics." Cambridge Review of International Affairs 32, no. 3 (2019): 283-302.

Kirdis, Esen and Amina Drmiheur. "The Rise of Populism? Comparing Incumbent Pro-Islamic Parties in Turkey and Morocco." Turkish Studies 17, no. 4 (2016): 599-617.

Kizilkan-Kisacik, Zelal B. "The Impact of the EU on Minority Rights: The Kurds as a Case." In The Kurdish Question in Turkey: New Perspectives on Violence, Representation, and Reconciliation, edited by Cengiz Gunes and Welat Zeydanlioglu, 205-24. New York: Routledge, 2014.

Krolikowski, Alanna. "State Personhood in Ontological Security Theories of International Relations and Chinese Nationalism: A Sceptical View." The Chinese Journal of International Politics 2, no. 1 (2008): 109-33.

Laing, Ronald. The Divided Self: An Existential Study in Sanity and Madness. New York: Pelican, 1960.

Milliyet. "Secime Parti Olarak Girecegiz." December 15, 2014, https://www.milliyet.com.tr/gundem/ secime-parti-olarak-girecegiz-1984367.

—_. "Erdoğan: 400 Milletvekili Lazim." February 2, 2015, https://www.milliyet.com.tr/siyaset/erdogan400-milletvekili-lazim-2009741

Mitzen, Jennifer. "Ontological Security in World Politics: State Identity and the Security Dilemma." European Journal of International Relations 12, no. 3 (2006): 341-70.

Moffitt, Benjamin. "How to Perform Crisis: A Model for Understanding the Key Role of Crisis in Contemporary Populism." Government and Opposition 50, no. 2 (2015): 189-217.

Mudde, Cas. "The Populist Zeitgeist." Government and Opposition 39, no. 3 (2004): 541-63.

Muller, Jan-Werner. What is Populism? London: Penguin Books, 2017.

NBC New York. "Trump: Open Border Cost American Lives." September 17, 2016, https://www.nbcnewyork. com/news/national-international/trump-speaks-at-anti-illegal-immigration-groups-conference/2038428/.

NTV. "Yenikapi'da “Terore Karsi Tek Ses" Mitingi." September 20, 2015, https://www.ntv.com.tr/turkiye/ yenikapida-terore-karsi-miting,hj4aln45CEyO19ak-XaEJg.

O'Driscoll, Dylan and Bahar Baser. "Independence Referendums and Nationalist Rhetoric: The Kurdistan Region of Iraq." Third World Quarterly 40, no. 11 (2019): 2016-34.

Ostiguy, Pierre and Kenneth Roberts. "Putting Trump in Comparative Perspective: Populism and the Politicization of the Cultural Low." The Brown Journal of World Affairs 23, no. 1 (2016): 25-50.

Ozkahraman, Cemal. "Failure of Peace Talks between Turkey and the PKK: Victim of Traditional Policy or of Geopolitical Shifts in the Middle East?" Contemporary Review of the Middle East 4 no. 1 (2017): 50-66.

Ozpek, Burak Bilgehan. "Paradigm Shift between Turkey and Kurds: From 'Clash of the Titans' to 'Game of Thrones'." Middle East Critique 27, no. 1 (2018): 43-60.

"The State's Changing Role Regarding the Kurdish Question of Turkey: From Consistent Tutelage to Volatile Securitization." Alternatives: Global, Local, Political 44, no. 1 (2019): 35-49.

Ozpek, Burak Bilgehan and Nebahat Tanriverdi Yaşar "Populism and Foreign Policy in Turkey under the AKP Rule." Turkish Studies 19, no. 2 (2018): 198-216.

Park, Bill. "Populism and Islamism in Turkey." Turkish Studies 19, no. 2 (2018): 169-75.

Post Medya. "AKP'li Vekil Orhan Miroglu'ndan Skandal Tehdit: HDP Baraji Gecerse Catisma Artar!" September 20, 2015, https://www.youtube.com/watch?v=qFphsZ6KKyQ. 
Reuters. "Venezuela's Maduro Defies Foreign Censure, Offers 'Prize' to Voters." May 3, 2018, https://www. reuters.com/article/us-venezuela-election/venezuelas-maduro-defies-foreign-censure-offers-prizeto-voters-idUSKBN1141 KK.

_. "Maduro Vows Economic Change for Venezuela's 'Rebirth' before Vote." May 15, 2018, https://www. reuters.com/article/us-venezuela-election/maduro-vows-economic-change-for-venezuelas-rebirthbefore-vote-idUSKCN1IG31S.

Sabah. “Gerekirse Baldiran Zehiri Icerim.” February 26, 2013, https://www.sabah.com.tr/gundem/2013/02/ 26/gerekirse-baldiran-zehri-icerim.

__. "Cumhurbaskani Erdoğan: Oleceksek Adam Gibi Olelim." October 26, 2015, https://www.sabah.com. tr/video/turkiye/cumhurbaskani-erdogan-oleceksek-adam-gibi-olelim.

Saracoglu, Cenk. "Exclusive Recognition': The New Dimensions of the Question of Ethnicity and Nationalism in Turkey." Ethnic and Racial Studies 32, no. 4 (2019): 640-58.

Schmidt, Vivian. "Discursive Institutionalism: The Explanatory Power of Ideas and Discourse." Annual Review of Political Science, no. 11 (2008): 303-26.

Selçuk, Orcun. "Strong Presidents and Weak Institutions: Populism in Turkey, Venezuela and Ecuador." Southeast European and Black Sea Studies 16, no. 4 (2016): 571-89.

Shlykov, Pavel. "Peace Process, International Organizations and the 'Kurdish Question'." In The Palgrave Handbook of Global Approaches to Peace, edited by Aigul Kulnazarova and Vesselin Poposki, 519-44. Cham: Palgrave Macmillan, 2019.

Somer, Murat. (2019). "Turkey: The Slippery Slope from Reformist to Revolutionary Polarization and Democratic Breakdown." ANNALS, AAPSS 681 (2019): 42-61.

Taggart, Paul. Populism. Buckingham: Open University Press, 2000.

_. "Populism and Representative Politics in Contemporary Europe." Journal of Political Ideologies 9, no. 3 (2004): 269-88.

Tas, Hakki. "Turkey - from Tutelary to Delegative Democracy." Third World Quarterly 36, no. 4 (2015): 776-91.

Tezcur, Gunes Murat. "When Democratization Radicalizes? The Kurdish Nationalist Movement in Turkey." Journal of Peace Research 47, no. 6 (2010): 775-89.

Türk, H. Bahadir. "'Populism as a Medium of Mass Communication': The Case of Recep Tayyip Erdoğan." International Area Studies Review 21, no. 2 (2018): 150-68.

Turkiye. "Erdoğan, Bundan Sonra Cozum Sureci Buzdolabina Kaldirilmistir." August 11, 2015, https://www. turkiyegazetesi.com.tr/politika/296110.aspx.

—. "Cumhurbaskani Erdoğan: Demokrasi Degil Ihanet Sorunu." September 9, 2015, https://www. turkiyegazetesi.com.tr/gundem/304179.aspx.

Turkiye Cumhuriyeti Cumhurbaskanligi. “13. Muhtarlar Bulusmasi'nda Yaptiklari Konusma.” October 26, 2015, https://www.tccb.gov.tr/konusmalar/353/35910/13-muhtarlar-toplantisinda-yaptiklari-konusma.

Weiss, Matthew. "From Constructive Engagement to Renewed Estrangement? Securitization and Turkey's Deteriorating Relations with Its Kurdish Minority." Turkish Studies 17, no. 4 (2016): 567-98.

Weyland, Kurt. "Clarifying a Contested Concept: Populism in the Study of Latin American Politics." Comparative Politics 34, no. 1 (2001): 1-22.

Yabanci, Bilge. "Populism as the Problem Child of Democracy: The AKP's Enduring Appeal and the Use of Meso-Level Actors." Southeast European and Black Sea Studies 16, no. 4 (2016): 591-617.

Yabanci, Bilge and Dane Taleski. "Co-Opting 'the Religion': How Ruling Populists in Turkey and Macedonia Sacralise the Majority." Religion, State \& Society 46, no. 3 (2018): 283-304.

Yegen, Mesut. "The Kurdish Question in Turkish State Discourse." Journal of Contemporary History 34, no. 4 (1999): 555-68. 